\title{
Assessment and Forecast of the Efficiency of Use of the Financial Resources of Amalgamated Territorial Communities in the Context of European Integration
}

\author{
By Roman Khirivskyi ${ }^{1}$, Liudmyla Petryshyn ${ }^{1}$, Tymofii Pasichnyk ${ }^{2}$, Oksana Brukh ${ }^{1}$, \\ Iryna Bernatska ${ }^{1}$, Lesia Kucher ${ }^{3}$
}

\begin{abstract}
The task of forecasting in economics is fulfilled by developing a variety of econometric models. The complexity of actual relations between the economic indices requires improvement of the existing and creation of new methods of modeling. That diversity is limited by the current set of elementary mathematical functions, whereas some of them cannot be applied in economics. At the beginning of the 21 st century, it was proposed to use the functions of complex variable in economics. Due to their properties, which differ from the functions of real variables, they describe relations between the economic indices in a different way. Particularly, exponential presentation of a complex variable provides easy assessment of the relations between the economic index, presenting the real part of the complex number and the index, which describes its imaginary part. The trigonometric representation of the complex variable provides a more precise assessment of the studied econometric indices. Basing on the theory of the functions of complex variable, the authors of the article make assessment of the efficiency of funds use by the communities in Lviv region. In particular, the relation of the dynamics of income per one resident and the costs for maintenance of the managerial apparatus in terms of one resident in each of the amalgamated territorial community is considered as a function of complex variable. Using the statistical data, the authors have developed modules of complex variables and their arguments, which demonstrate the dynamics of relations between those components. The work also presents developed exponential functions of complex variable with the real coefficients, which have high approximation properties and can be used to make forecast of the efficient use of funds of each ATC in the future. The methodology can be used not only for assessment of the efficiency of funds use by amalgamated territorial communities, but also for evaluation of the general activity of communities, as well as for the analysis and forecast of production processes and planning on different enterprises.
\end{abstract}

Keywords: complex numbers, economic and mathematical modeling, nonlinear models, territorial communities, Lviv region, social development, efficiency of the use of funds.

\section{Introduction}

Development of local government requires an effective mechanism of use of the financial resources of local budgets and satisfaction of various needs of population at the regional level. The efficient use of the resource potential of amalgamated territorial communities is closely connected with application of the economic analysis. Some of the most developed methods of economic analysis include economic and mathematical methods, which are mainly developed due to improvement of the existing methods and models. New directions of development of the instrumental base of the economic 
analysis emerge not very often. The main reserve of that process is observed in the use of the directions of modern mathematics, which, because of different reasons, have not been used in the economic and mathematical modeling. One of those directions is represented by the theory of the functions of complex variable, which has not been widely used in economics.

The problems of the efficient use of the financial funds of amalgamated territorial communities in Ukraine were studied by N. Kulchytska, L. Dermanska, T. Yakovets [11], O. Nezdoimynoha [15], K. Pavliuk [16], R. Khirivskyi, H. Cherevko, I. Yatsiv, T. Pasichnyk, L. Petryshyn, L. Kucher [5, 25]. The issues, related with development of the territorial communities in context of implementation of the policy of sustainable development, and the problems of decentralization are considered in the works by Y. Petrushenko, A. Vorontsova, O. Ponomarenko, K. Derbenov [18], A. Korbutiak, Z. Lysenko, N. Sokrovolska, A. Oleksyn, E. Yurii [7], the business potential and business-model of rural territories development are concerned in the researches by M. Strussová [22], O. Prokopchuk, T. Usyuk [20], M. Babych [2], V. Chemerys, V. Dushka, V. Maksym, D. Solomonko [3], I. Kravchuk, A. Rakovich [9]. The issues, related with financial support of sustainable development of Ukrainian agricultural sector and rural areas in the context of European integration are considered in the works by E. Kirieieva et al. [6], O. Kravchenko et al. [8], A. Kucher [10]; the role of public investment policy and responsible investment in sustainable development financing and budgetary revenue structure at central level of public administration are concerned in the researches by A. Plastun et al. [19], N. Rekova [21]. In those works, as well as in the most cases of economic and mathematical modeling, the researchers mostly use the methods and models, which describe and study the behavior of a set of indices, whereas do not reveal the casual relations $[4,26,12,17]$. In the simplest case, they use the trends, considering the simple principle, i.e. it is assumed that because of inertia, which is particular for the economic systems, the established tendencies will continue in the forecasted future.

Nevertheless, in practice, the expectation is often not justified, and thus the accuracy of the forecasts, made by means of such models, is not very high. However, it is worth mentioning that they are the most popular models of forecasting, widely used in the economic practice and in the science of forecasting.

In the attempts to obtain better economic forecasts, scientists develop the models, in which the expected index is calculated using the instruments of the regression analysis $[12,14,25]$. Such models are developed on the most adequate preconditions, because only having detected and described the cause and effect relations of a complicated object, one can understand the peculiarities of its behavior and make a more accurate forecast. However, in economics, such approach does not always work in a proper way, i.e. any assumed index depicts the economic phenomenon, which is a result of actions and interaction of many factors of different nature. Thus, the impact of such factors is very complex, and often has nonlinear character with a time delay.

The so-called analysis of economics on the base of complex variables is one of the promising directions to solve the problems of economic forecasting [13, 23].

According to S. Svietunkov, the complex variables have specific properties, differing from the functions of real variables, and thus describe the relations between the 
economic indices in a different way [24]. Particularly, on the example of the theory of production functions, he proved that use of the complex variables greatly expanded the instruments of the economic analysis of production processes.

Thus, to study the efficiency of use of the funds of amalgamated territorial communities in Lviv region, the authors of the work choose the methodology of complex variables.

\section{Materials and Methods}

The aim of the article is to make assessment and forecast of efficiency of use of financial resources of amalgamated territorial communities of the region in context of the European integration.

A complex number is a number, which consists of two parts, particularly real and imaginary. In algebraic form, the complex number $z$ looks like:

$\mathrm{z}=\mathrm{zr}+\mathrm{izi}$,

where $\mathrm{zr}$ - stands for a real part, izi - stands for an imaginary part, zr, zi - stand for real numbers, $i$ - stands for an imaginary one (number, which satisfies the equality i2 = -1).

A complex number is a normal mathematical abstraction, similar to, for example, rational or irrational number. In different technical sciences, particularly in physics and in electric engineering, the complex numbers are used rather actively. However, presentation of variables in the real and imaginary parts of a complex number is explained by some laws. For instance, in electrical engineering, it is considered that the value of the active capacity should refer to the real part, whereas reactive - to the imaginary one. In economics, there are no such conceptual correspondences to the real and imaginary parts of a complex variable. Nevertheless, presentation of economic components in the form of a complex index secures investigating different aspects as an integrity.

\section{Results}

The econometric model of complex variables in the general form can be presented as a regressive dependence of the complex econometric index y on one or several complex variables $\mathrm{xj}$ :

$y=f(x j)+\varepsilon$,

Here, $\mathrm{y}-$ stands for a complex of resultant economic index, which consists of a real yr and imaginary yi parts; $x j$ - stands for a complex economic factor (or factors), which is considered as a reason of the dynamics y and consists of a real and imaginary part; $\varepsilon-$ stands for the approximation deviation.

It is important that by means of the imaginary one, it is possible to combine two (or more) economic indices into one complex index.

As far as the complex variable can be presented not only in arithmetic form, but also in

$\mathrm{y}=\mathrm{yr}+\mathrm{iyi}=\mathrm{ReiQ}$

a trigonometric one

$\mathrm{y}=\mathrm{R} \cos \mathrm{Q}+\mathrm{iR} \sin \mathrm{Q}$,

its additional characteristics include a module of the complex variable:

$R=\sqrt{y_{r}^{2}+y_{i}^{2}}$, 
and its argument:

$$
Q=\operatorname{arctg} \frac{y_{i}}{y_{r}},
$$

Before using the above-mentioned complex variables in the models, it is necessary to consider a set of conditions of their use:

1. Economic indices, which are consolidated into one complex variable, should include two characteristics of one process of phenomenon, i.e. depict different sides of that phenomenon. Thus, there should be a relation both between the variables and between the real and imaginary parts of each variable.

2. The indices should be of the same dimension.

3. Random values should be normally distributed.

To study the efficiency of use of the funds of amalgamated territorial communities in Lviv region by the method of complex variable, the authors of the work consider the dynamics of income per one resident ( $\mathrm{yr}$ ) and spending for maintenance of the managerial apparatus on a per one resident basis (yi).

The first index characterizes the financial potential of ATC, capability to supply the community by means of resources, which are generated on its territory. The second index demonstrates the "cost" of one employee of the managerial apparatus of the ATC for each resident of the community (on per a year basis). Those data are presented in the Table 1.

Table 1: Principal figures of the amalgamated territorial communities

\begin{tabular}{|c|c|c|c|c|c|c|}
\hline \multirow[b]{3}{*}{ ATC in Lviv region } & \multicolumn{6}{|c|}{ Years } \\
\hline & \multicolumn{2}{|c|}{2017} & \multicolumn{2}{|c|}{2018} & \multicolumn{2}{|c|}{2019} \\
\hline & 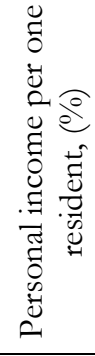 & 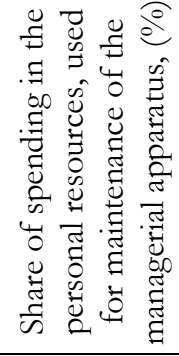 & 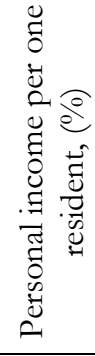 & 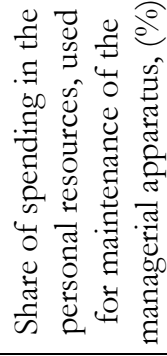 & 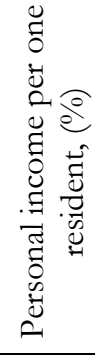 & 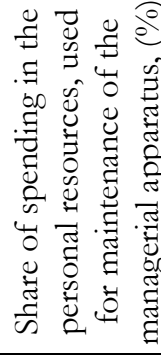 \\
\hline Babyna & 35.21 & 25.70 & 12.37 & 51.30 & 6.71 & 61.20 \\
\hline Biskovychi & 13.19 & 38.60 & 6.09 & 52.00 & 3.37 & 44.20 \\
\hline Vilshanyk & 4.88 & 75.30 & 3.35 & 78.60 & 0.97 & 82.10 \\
\hline Volia Baranetska & 4.67 & 68.90 & 3.03 & 85.90 & 0.79 & 87.10 \\
\hline Hnizdychiv & 17.17 & 26.90 & 8.25 & 23.00 & 7.26 & 22.40 \\
\hline Hrabovets & 14.43 & 60.00 & 7.38 & 58.40 & 4.68 & 55.60 \\
\hline Davydiv & 38.71 & 24.80 & 18.29 & 30.40 & 17.11 & 23.60 \\
\hline Dubliany & 17.63 & 34.20 & 7.55 & 35.30 & 4.51 & 39.90 \\
\hline Zhovtantsi & 26.81 & 20.90 & 13.20 & 21.40 & 10.14 & 20.70 \\
\hline Zabolottsi & 20.46 & 28.90 & 11.36 & 26.70 & 12.37 & 26.90 \\
\hline Lukiv & 5.10 & 55.90 & 2.95 & 69.20 & 0.93 & 64.80 \\
\hline Mizhenets & 8.33 & 60.10 & 4.15 & 74.50 & 1.20 & 86.10 \\
\hline
\end{tabular}




\begin{tabular}{|l|c|c|c|c|c|c|}
\hline Mostyska & 26.43 & 15.40 & 9.61 & 21.80 & 6.40 & 20.70 \\
\hline Nyzhankovychi & 14.67 & 35.30 & 6.21 & 52.90 & 3.86 & 46.30 \\
\hline Novyi Kalyniv & 28.91 & 30.30 & 12.49 & 35.80 & 9.98 & 34.40 \\
\hline Nove Misto & 4.61 & 53.00 & 2.75 & 62.30 & 0.52 & 60.60 \\
\hline Novi Strilyshcha & 21.85 & 38.10 & 9.73 & 39.70 & 5.03 & 43.00 \\
\hline Sudova Vyshnia & 12.65 & 28.50 & 7.04 & 34.90 & 4.30 & 34.60 \\
\hline Trostianets & 42.75 & 16.90 & 16.30 & 23.00 & 11.25 & 27.00 \\
\hline Khodoriv & 20.62 & 18.20 & 8.50 & 24.60 & 6.25 & 21.70 \\
\hline Chukva & 8.53 & 58.50 & 4.70 & 64.80 & 2.57 & 59.20 \\
\hline Shehyni & 34.90 & 25.80 & 15.86 & 32.50 & 12.69 & 27.80 \\
\hline
\end{tabular}

Source: The Table is composed on the base of the data of the communities and electronic resource [1].

The Table 1 demonstrates that reduction of values of the module (1) can happen in the variant of reduction of at least one of its economic components. Stability of the module, under the growth of one index, confirms a reduction of another one. It can be diagnosed by the argument dynamics. Reduction of the argument confirms that the fraction numerator (2) decreases as compared to the denominator.

The Table 2 proves that the argument does not go up only in Davydiv and Zabolottsi ATC. Thus, in all other communities, spending for maintenance of the managerial apparatus increases faster than the personal income per one resident of the ATC. It confirms an inefficient use of the funds of the ATC.

Table 2: Argument of the indices of spending for maintenance of the managerial apparats relating to the personal funds in the amalgamated territorial communities in Lviv region

\begin{tabular}{|l|c|c|c|l|c|c|c|}
\hline \multirow{2}{*}{$\begin{array}{l}\text { ATC in Lviv } \\
\text { region }\end{array}$} & \multicolumn{3}{|c|}{ Years } & ATC in Lviv & \multicolumn{3}{|c|}{ Years } \\
\cline { 2 - 5 } & 2017 & 2018 & 2019 & region & 2017 & 2018 & 2018 \\
\hline Babyna & 0.6305 & 1.3341 & 1.4615 & Mizhenets & 1.4331 & 1.5151 & 1.5569 \\
\hline Biskovychi & 1.2415 & 1.4543 & 1.4946 & Mostyska & 0.5276 & 1.1556 & 1.2709 \\
\hline Vilshanyk & 1.5060 & 1.5282 & 1.5589 & Nyzhankovychi & 1.1769 & 1.4539 & 1.4875 \\
\hline Volia Baranetska & 1.5032 & 1.5356 & 1.5618 & Novyi Kalyniv & 0.8089 & 1.2350 & 1.2885 \\
\hline Hnizdychiv & 1.0028 & 1.2265 & 1.2572 & Nove Misto & 1.4840 & 1.5267 & 1.5622 \\
\hline Hrabovets & 1.3348 & 1.4452 & 1.4868 & Novi Strilyshcha & 1.0501 & 1.3304 & 1.4544 \\
\hline Davydiv & 0.5698 & 1.0292 & 0.9434 & Sudova Vyshnia & 1.1531 & 1.3716 & 1.4471 \\
\hline Dubliany & 1.0948 & 1.3602 & 1.4584 & Trostianets & 0.3764 & 0.9542 & 1.1761 \\
\hline Zhovtantsi & 0.6622 & 1.0182 & 1.1153 & Khodoriv & 0.7232 & 1.2381 & 1.2906 \\
\hline Zabolottsi & 0.9548 & 1.1684 & 1.1399 & Chukva & 1.4261 & 1.4984 & 1.5274 \\
\hline Lukiv & 1.4797 & 1.5282 & 1.5564 & Shehyni & 0.6366 & 1.1168 & 1.1427 \\
\hline
\end{tabular}

Source: Composed by the authors using the formula (6).

The experience of scientific researches demonstrates that nonlinear models are the most effective for solution of the economic problems [7]. The exponential production function of complex variable with real coefficients [11] is one of the simplest forms of nonlinear complex-number models of production functions. It has the following form:

$y_{r}+i y_{i}=\left(a_{0}+i a_{1}\right) t^{\left(b_{0}+i b_{1}\right)}$

To find the unknown parameters $\left(a_{0}, a_{1}, b_{0}, b_{1}\right)$ of the model $(7)$, the authors of the research use the methodology of assessment of the parameters of nonlinear models of 
complex variable with complex coefficients. Thus, the equation (7) should be first brought to the linear form by taking the natural logarithm of the left and right part of the model. It results in obtaining of the following linear equation:

$$
\ln \left(y_{r}+i y_{i}\right)=\ln \left(a_{0}+i a_{1}\right)+\left(b_{0}+i b_{1}\right) \ln t
$$

Having applied the method of the smallest squares for calculation of the coefficients of the present model, the researchers obtain a system of equations of the following kind:

$$
\begin{aligned}
& a_{0} n+b_{0} \sum_{t} x_{r t}-b_{1} \sum_{t} x_{i t}=\sum_{t} y_{r t} \\
& a_{1} n+b_{0} \sum_{t}^{t} x_{i t}+b_{1} \sum_{t}^{t} x_{r t}=\sum_{t} y_{i t} \\
& a_{0} \sum_{t} x_{r t}+a_{1} \sum_{t} x_{i t}+b_{0} \sum_{t}\left(x_{r t}^{2}+x_{i t}^{2}\right)=\sum_{t} y_{r t} x_{r t}+\sum_{t} y_{i t} x_{i t}, \\
& -a_{0} \sum_{t} x_{i t}+a_{1} \sum_{t} x_{r t}+b_{1} \sum_{t}\left(x_{r t}^{2}+x_{i t}^{2}\right)=\sum_{t} y_{i t} x_{r t}+\sum_{t} y_{r t} x_{i t}
\end{aligned}
$$

which results in calculation of the coefficients figures by the formulas:

$$
\begin{gathered}
a_{0}=\frac{\sum_{t}\left(x_{r t}^{2}+x_{i t}^{2}\right) \cdot \sum_{t} y_{r t}-\sum_{t} x_{r t} \cdot\left(\sum_{t} y_{r t} x_{r t}+\sum_{t} y_{i t} x_{i t}\right)+\sum_{t} x_{i t} \cdot\left(\sum_{t} y_{i t} x_{r t}+\sum_{t} y_{r t} x_{i t}\right)}{D} \\
a_{1}=\frac{\sum_{t}\left(x_{r t}^{2}+x_{i t}^{2}\right) \cdot \sum_{t} y_{i t}-\sum_{t} x_{r t} \cdot\left(\sum_{t} y_{i t} x_{r t}+\sum_{t} y_{r t} x_{i t}\right)-\sum_{t} x_{i t} \cdot\left(\sum_{t} y_{r t} x_{r t}+\sum_{t} y_{i t} x_{i t}\right)}{D} \\
b_{0}=\frac{n \cdot\left(\sum_{t} y_{r t} x_{r t}+\sum_{t} y_{i t} x_{i t}\right)-\sum_{t} x_{r t} \cdot \sum_{t} y_{r t}-\sum_{t} x_{i t} \cdot \sum_{t} y_{i t}}{D} \\
b_{1} \frac{n \cdot\left(\sum_{t} y_{i t} x_{r t}+\sum_{t} y_{r t} x_{i t}\right)+\sum_{t} x_{i t} \cdot \sum_{t} y_{r t}-\sum_{t} x_{r t} \cdot \sum_{t} y_{i t}}{D}
\end{gathered}
$$

where:

$$
D=n \sum_{t}\left(x_{r t}^{2}+x_{i t}^{2}\right)-\left(\sum_{t} x_{r t}\right)^{2}-\left(\sum_{t} x_{i t}\right)^{2},
$$

$n-$ stands for the number of samples.

Using the (11) and data of the Table 1, the authors have composed regression models of the trends of each of the considered ATC and obtained the following results (Table 3).

Table 3: Parameters of the developed models for the ATC in Lviv region

\begin{tabular}{|l|c|c|c|c|}
\hline \multirow{2}{*}{ ATC } & \multicolumn{4}{|c|}{ Coefficients } \\
\cline { 2 - 5 } & $a_{0}$ & $a_{1}$ & $b_{0}$ & $b_{1}$ \\
\hline Babyna & 0.425243 & 0.08235 & 0.310068 & 0.784295 \\
\hline Biskovychi & 0.087327 & 0.418714 & 0.106309 & 0.238647 \\
\hline Vilshanyk & 0.262326 & -0.705280 & 0.075053 & 0.046425 \\
\hline Volia Baranetska & 0.247898 & -0.657530 & 0.22256 & 0.052649 \\
\hline Hnizdychiv & 0.261685 & 0.172418 & -0.28828 & 0.241368 \\
\hline Hrabovets & 0.038642 & 0.618335 & -0.08917 & 0.140649 \\
\hline Davydiv & 0.395898 & -0.239800 & -0.41027 & 0.374851 \\
\hline Dubliany & 0.203644 & 0.316637 & 0.024705 & 0.336540 \\
\hline Zhovtantsi & 0.321088 & -0.096740 & -0.3624 & 0.423351 \\
\hline
\end{tabular}




\begin{tabular}{|l|c|c|c|c|}
\hline Zabolottsi & 0.323455 & 0.125158 & -0.17628 & 0.183529 \\
\hline Lukiv & 0.176331 & -0.550130 & 0.149365 & 0.069823 \\
\hline Mizhenets & 0.131004 & -0.590340 & 0.316473 & 0.113335 \\
\hline Mostyska & 0.291448 & -0.084690 & -0.31887 & 0.701265 \\
\hline Nyzhankovychi & 0.126238 & 0.381610 & 0.209966 & 0.295313 \\
\hline Novyi Kalyniv & 0.401976 & 0.117164 & -0.14239 & 0.455727 \\
\hline Nove Misto & 0.170149 & -0.514500 & 0.130489 & 0.070113 \\
\hline Novi Strilyshcha & 0.271907 & 0.336503 & -0.02287 & 0.371978 \\
\hline Sudova Vyshnia & 0.142941 & 0.282394 & 0.111336 & 0.272768 \\
\hline Trostianets & 0.304389 & -0.314570 & -0.44323 & 0.739226 \\
\hline Khodoriv & 0.276752 & 0.039971 & -0.16863 & 0.540775 \\
\hline Chukva & 0.102961 & -0.595710 & 0.016557 & 0.093523 \\
\hline Shehyni & 0.427683 & -0.094920 & -0.31331 & 0.485649 \\
\hline
\end{tabular}

Source: Composed by the authors.

The data demonstrate that the trends describe the established tendency and can serve as the models, which provide a reliable forecast on the general tendency of the efficiency of use of the funds of amalgamated territorial communities in Lviv region by the method of complex variable.

According to the data of the Table 3, the researchers make a forecast of the personal funds per one resident and the share of spending for maintenance of the managerial apparatus in each of the studied ATC at the end of 2020 (Table 4).

Table 4: Forecasted quantitative indices of amalgamated territorial communities for 2020

\begin{tabular}{|c|c|c|c|c|c|}
\hline $\begin{array}{l}\text { ATC in Lviv } \\
\text { region }\end{array}$ & 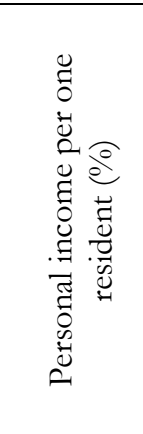 & 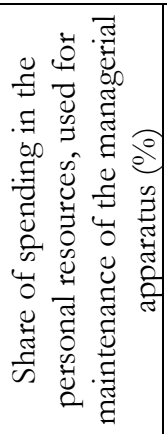 & $\begin{array}{l}\text { ATC in Lviv } \\
\text { region }\end{array}$ & 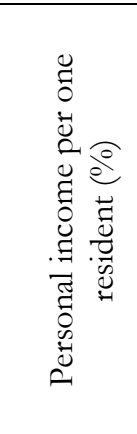 & 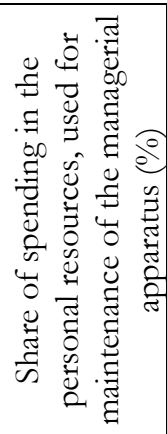 \\
\hline Babyna & 0.153974 & 0.711776 & Mizhenets & 0.002835 & 1.331420 \\
\hline Biskovychi & 0.000624 & 0.567017 & Mostyska & 0.106928 & 0.248139 \\
\hline Vilshanyk & 0.004754 & 0.910242 & Nyzhankovychi & 0.016710 & 0.508756 \\
\hline Volia Baranetska & 0.000514 & 1.181173 & Novyi Kalyniv & 0.105385 & 0.394315 \\
\hline Hnizdychiv & 0.061141 & 0.218999 & Nove Misto & 0.001634 & 0.664728 \\
\hline Hrabovets & 0.015757 & 0.631743 & Novi Strilyshcha & 0.059496 & 0.359630 \\
\hline Davydiv & 0.161152 & 0.226132 & Sudova Vyshnia & 0.030709 & 0.338625 \\
\hline Dubliany & 0.057143 & 0.412444 & Trostianets & 0.193025 & 0.243760 \\
\hline Zhovtantsi & 0.155720 & 0.047192 & Khodoriv & 0.098701 & 0.122634 \\
\hline Zabolottsi & 0.157981 & 0.273651 & Chukva & 0.001817 & 0.696763 \\
\hline Lukiv & 0.000649 & 0.648957 & Shehyni & 0.106556 & 0.264171 \\
\hline
\end{tabular}

Source: The Table is composed by the authors using the formula (7). 


\section{Conclusions}

Basing on the theory of the functions of complex variable, the authors of the article make assessment of the efficiency of funds use by the communities in Lviv region. In particular, the relation of the dynamics of income per one resident and the costs for maintenance of the managerial apparatus in terms of one resident in each of the amalgamated territorial community is considered as a function of complex variable. Using the statistical data, the authors have developed modules of complex variables and their arguments, which demonstrate the dynamics of relations between those components. The work also presents developed exponential functions of complex variable with the real coefficients, which have high approximation properties and can be used to make forecast of the efficient use of funds of each ATC in the future. The methodology can be used not only for assessment of the efficiency of funds use by amalgamated territorial communities, but also for evaluation of the general activity of communities, as well as for the analysis and forecast of production processes and planning on different enterprises.

It is clear that to increase the accuracy of the forecast by means of a complex trend (11), the following researches should be devoted to adaptation of the model coefficients to the conditions, which change during the time. Moreover, making forecast of the general tendency of the complex index dynamics, one should remember that the level of social and economic development of the region is the result of an active economic impact of both regional administrations and the government of Ukraine. It means that the established tendencies can significantly change any moment. Thus, the complex trends of the real argument of social and economic dynamics can be used to answer the question whether economic activity of the communities is efficient under unchanged social and economic policy. Hence, it is necessary to assess the module of the complex variable and its argument. It is argued that the developed trends are unable to answer the question of what should be done to change the situation and the tendency of the social and economic dynamics. The answer to the question can be found in application of more complicated multi-factorial models of complex variables.

\section{References}

Assessment of financial capacity of 366 ATC in 2017. Available at: https://decentralization.gov.ua

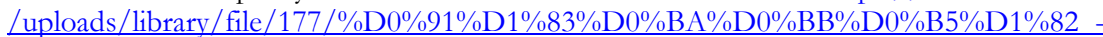
$\% \mathrm{D} 0 \% \mathrm{~A} 0 \% \mathrm{D} 0 \% \mathrm{~B} 5 \% \mathrm{D} 0 \% \mathrm{~B} 9 \% \mathrm{D} 1 \% 82 \% \mathrm{D} 0 \% \mathrm{~B} 8 \% \mathrm{D} 0 \% \mathrm{BD} \% \mathrm{D} 0 \% \mathrm{~B} 3 \% \mathrm{D} 1 \% 84 \% \mathrm{D} 1 \% 96 \%$ D0\%BD. $\%$ D $1 \% 81 \% \mathrm{D} 0 \% \mathrm{BF} \% \mathrm{D} 1 \% 80 \% \mathrm{D} 0 \% \mathrm{BE} \% \mathrm{D} 0 \% \mathrm{BC} 366 \% \mathrm{D} 0 \% 9 \mathrm{E} \% \mathrm{D} 0 \% \mathrm{~A} 2 \% \mathrm{D} 0 \% 9$ $3 \% \mathrm{D} 0 \% \mathrm{~B} 7 \% \mathrm{D} 0 \% \mathrm{~B} 02017 . \mathrm{pdf}$.

Babych, M. (2018). Social-economic and environmental sustainability of short supply chains: opportunities for development rural territories. Agricultural and Resource Economics, 4(1): 42-59. Available at: http://are-journal.com.

Chemerys, V., Dushka, V., Maksym, V. and Solomonko, D. (2019). Business-model of rural areas development in Ukraine. Agricultural and Resource Economics, 5(1): 154-176. Available at: http://are-journal.com.

Draper, N. and Smith, G. (2007). Applied regression analysis. Moscow: Publishing house "Williams". 912 p.

Khirivskyi, R., Cherevko, H., Yatsiv, I., Pasichnyk, T., Petryshyn, L. and Kucher, L. (2020). Assessment and analysis of sustainability of the socio-economic development of amalgamated territorial communities of the region. European Journal of Sustainable Development, 9(2), 569-578. https://doi.org/10.14207/ejsd.2020.v9n2p569. 
Kirieieva, E. A., Pryshliak, N. V., Shamanska, O. I., Salkova, I. Yu. Kucher, A. V. (2019). Strategic priorities and financial support of Ukrainian agricultural sector development. International Journal of Ecological Economics \& Statistics, 40(2), 25-37.

Korbutiak, A. Lysenko, Z., Sokrovolska, N., Oleksyn, A. and Yurii, E. (2019). United territorial communities in Ukraine in the context of fiscal decentralization. Problems and Perspectives in Management, 17(2): 217-227. https://doi.org/10.21511/ppm.17(2).2019.16.

Kravchenko, O., Kucher, A., Hełdak, M., Kucher, L. and Wysmułek, J. (2020). Socio-economic transformations in Ukraine towards the sustainable development of agriculture. Sustainability, 12(13): 5441. https://doi.org/10.3390/su12135441.

Kravchuk, I. and Rakovich, A. (2018). Entrepreneurial potential of rural territories as an object of scientific research. Agricultural and Resource Economics, 4(2): 69-84. Available at: http://are-journal.com.

Kucher, A. (2017), Development of rural areas based on rational agricultural land use: a case study of Ukraine. Strategies for the agri-food sector and rural areas - dilemmas of development: monograph; eds: M. Wigier, A. Kowalski. Warsaw: Institute of Agricultural and Food Economics - National Research Institute. Pp. 120-135.

Kulchytska, N., Dermanska, L. and Yakovets, T. (2020). Assessment of efficiency of financial activities of ATC in decentralization conditions. Worth of finance, 4(61): 111-124.

Malov, S. V. (2013). Regression analysis. Theoretical fundamentals and practical recommendations. SPb: Publishing house of Saint-Petersburg University. 276 p.

Merkulova, T. V. and Prykhodko, A. I. (2010). Application of the functions of complex variables in econometric modeling. Bulletin of Kharkiv National University named after V. N. Karazin. Series: Economic, 884: 134-140. Available at: http://nbuv.gov.ua/UJRN/VKhE 201088425.

Nelson, R. and Winters, S. (2000). Evolutional theory of economic transformations. Moscow: Finstatinform, $474 \mathrm{p}$.

Nezdoimynoha, O. Ye. (2017). Peculiarities of formation of the budget of the territorial community. Economics and society, 11: 443-449. Available at: http://www.economyandsociety.in.ua/journal/11_ukr/71.pdf.

Pavliuk, K. V. (2006). Spending of budgets for development of human capital as a factor of economic growth. Finance of Ukraine, 9: 30-46.

Petrova, I. L., Shpyliova, T. I. and Sysolina, N. P. (2010), Innovative activity: stimuli and obstacles. Kyiv: Dorado, 2010. 320 p.

Petrushenko, Y. M., Vorontsova, A. S., Ponomarenko, O. S. and Derbenov, K. O. (2019). Analysis of the united territorial communities strategies in the context of sustainable development policy implementation. Mechanism of economy regulation, 1: 33-45. https://doi.org/10.21272/mer.2018.83.02.

Plastun, A., Yelnikova, Y., Shelyuk, A., Vorontsova, A. and Artemenko, A. (2020). The role of public investment policy and responsible investment in sustainable development financing. Agricultural and Resource Economics, 6(2): 108-125. Available at: http://are-journal.com.

Prokopchuk, O. and Usyuk, T. (2016), European model of the investment support of rural development policy. Agricultural and Resource Economics, 2(4): 149-160. Available at: http://are-journal.com.

Rekova, N., Dolozina, I., Nitsenko, V., Zaitsev, Y., and Zamlynskyi, V. (2018). Budgetary revenue structure at central level of public administration in the federal countries. Administratie si Management Public, 30: 37-50. https://doi.org/10.24818/amp/2018.30-03.

Strussová, M. (2005). Social and territorial identifications of the rural population and its activating potential. Agric. Econ. - Czech, 51: 565-574. https://doi.org/10.17221/5152-AGRICECON.

Svietunkov, S. H. (2008). Fundamentals of the theory of econometrics of complex variables. SPb.: Publishing house SPbSUE. 108 p.

Svietunkov, S. H. (2016). On the possibility of economic forecasting by using exponential production function of a complex variable. Economy of region, 12(3): 966-976. https://doi.org/10.17059/2016$\underline{3-29}$.

Yatsiv, I., Khirivskyi, R., Pasichnyk, T., Petryshyn, L. and Kucher, L. (2019). Assessment of the efficiency of resource potential employment by the communities of Lviv region of Ukraine. European Journal of Sustainable Development, 8(2): 165-176. https://doi.org/10.14207/ejsd.2019.v8n2p165.

Zatonskii, A. V. and Sirotina, N. A. (2014). Forecast of the economic systems on the model, based on the regression differentiated equation. Economics and mathematical methods, 50(5): 91-99. 